\title{
Optimalisasi Disiplin Kerja dan Kompetensi Karyawan Dalam Meningkatkan Kompensasi
}

\author{
Bambang Somantri ${ }^{1}$, Andi Riyanto ${ }^{2}$, Galih Raspati ${ }^{3}$, Eva Marsusanti ${ }^{4}$ \\ 1,3 Institut Manajemen Wiyata Indonesia \\ e-mail: ${ }^{1}$ bsomantri@imwi.ac.id, ${ }^{3}$ galih raspati@yahoo.com \\ 2,4 Universitas Bina Sarana Informatika \\ e-mail: ${ }^{2}$ andi.iio@bsi.ac.id, ${ }^{4} \underline{\text { eva.emr@bsi.ac.id }}$
}

\begin{abstract}
Abstrak
Tujuan penelitian adalah untuk mengetahui dampak disiplin kerja terhadap kompensasi, dampak kompetensi karyawan terhadap kompensasi, dan dampak disiplin kerja dan kompetensi karyawan terhadap kompensasi. Objek penelitian ini adalah karyawan yang bekerja di Hotel Selabintana. Jumlah responden dalam penelitian ini sebanyak 102 orang karyawan. Metode pengumpulan data melalui survei dengan menggunakan kuesioner. Pada penelitian ini menggunakan analisis regresi linier berganda. Hasil olah data menunjukkan bahwa disiplin kerja berpengaruh secara positif dan signifikan terhadap kompensasi dengan nilai 4,260 > 1,985 dan nilai signifikan $0,000<0,05$, kompetensi karyawan berpengaruh secara positif dan signifikan terhadap kompensasi dengan nilai 6,529 > 1,985 dan nilai signifikan 0,000 < 0,05, secara simultan disiplin kerja dan kompetensi karyawan berpengaruh signifikan terhadap kompensasi dengan nilai $281,549>3,09$ dan nilai signifikan $0,000<0,05$.
\end{abstract}

Kata Kunci: disiplin kerja, kompetensi karyawan, kompensasi.

\begin{abstract}
This study aims to determine the impact of work discipline on compensation, the impact of employee competence on compensation, and the impact of work discipline and employee competence on compensation. The subjects of this research are employees who work at Hotel Selabintana. The number of respondents in this study were 102 employees. The method of collecting data is through a survey using a questionnaire. The analytical technique used in this research is multiple linear regression analysis. The results showed that work discipline had a positive and significant effect on compensation with a value of $4.260>1.985$ and a significant value of $0.000<0.05$, employee competence had a positive and significant effect on compensation with a value of $6.529>1.985$ and a significant value of $0.000<0.05$, Simultaneously work discipline and employee competence have a significant effect on compensation with a value of $281,549>3.09$ and a significant value of $0.000<0.05$.
\end{abstract}

Keywords: work discipline, employee competence, compensation.

\section{Pendahuluan \\ Perkembangan industri jasa saat ini} terbilang cukup meningkat, dilihat dari banyaknya perusahan baru yang bergerak di bidang jasa, salah satunya yaitu jasa perhotelan, hal tersebut membuat tekanan persaingan bisnis semakin ketat. Karena pada dasarnya, industri jasa harus memiliki sumber daya manusia yang berkompeten, guna memuaskan para pelanggannya. Hal itu merupakan syarat wajib yang harus dipenuhi oleh pihak industri jasa, terutama di bidang jasa perhotelan.

Pelayanan hotel yang baik berasal dari sumber daya manusia yang kompeten 
dan profesional. Sehingga, segala permasalahan yang terjadi di hotel akan terselesaikan dengan cepat. Hotel akan berkembang dengan baik, jika sumber daya manusia atau karyawan yang dipilih berkompeten dan profesional. Untuk memilih karyawan berprestasi dan kompeten tidaklah mudah, dibutuhkan pemilihan yang selektif, dimulai dari prestasi apa saja yang sudah diraih, kompetensi apa yang dimiliki, serta berapa banyak kekuatan karyawan tersebut untuk mengemban amanah yang besar dalam mengelola industri jasa di bidang perhotelan. Lina (2020), menyatakan rekrutmen merupakan awal dari bagaimana mencapai tujuan organisasi yaitu menyeleksi orang-orang yang berkompeten, namun jika rekrutmen tidak melalui prosedur yang baik maka akan berdampak sebaliknya. Rekrutmen adalah langkah pertama dalam memutuskan masa depan perusahaan dan akuisisi pegawai seperti yang diharapkan..

Kinerja suatu perusahaan dipengaruhi oleh banyak faktor, antara lain disiplin kerja dan kompensasi. Disiplin adalah salah satu faktor kunci keberhasilan kinerja perusahaan, tanpa dukungan disiplin karyawan, sangat sulit bagi perusahaan untuk mencapai misinya (Ariani \& Widodo, 2020). Jika karyawan puas dengan kompensasi yang diberikan oleh perusahaan, mereka akan meningkatkan kedisiplinan terhadap aturan perusahaan yang akan mempengaruhi kinerja mereka (Mulyapradana, Rosewati, \& Muafiq, 2020; Pratama, 2020).

Berikut data absensi karyawan Hotel Selabintana selama tiga tahun terakhir, yaitu:

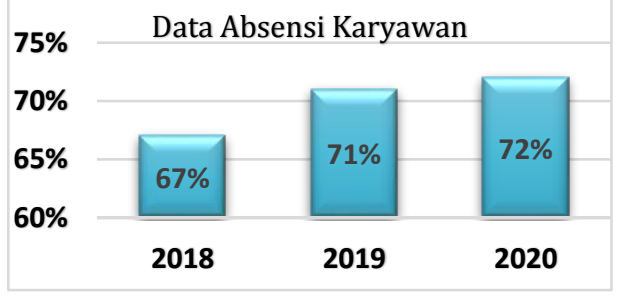

Gambar 1. Grafik Absensi Karyawan Hotel Selabintana Tahun 2018 - 2020.

Sumber: HRD Hotel Selabintana, (2020).

$$
\text { Setiap perusahaan perlu }
$$
melakukan promosi jabatan, selain untuk meningkatkan sumber daya manusia yang ada di perusahaan, bisa juga untuk meningkatkan kinerja karyawan, sehingga memberikan timbal balik yang baik untuk perusahaan, di mana visi, misi dan tujuan perusahaan dapat tercapai. Namun, melihat dari fenomena yang terjadi di Hotel Selabintana yang selama tiga tahun ke belakang belum melakukan promosi jabatan. Apa yang menyebabkan hal tersebut, apakah kurangnya pemberian kompensasi yang tidak sesuai sehingga membuat para karyawan tidak disiplin dalam bekerja, atau kompetensi karyawan yang tidak sesuai yang membuat kurangnya disiplin bekerja sehingga berimbas kepada promosi jabatan yang belum dilakukan lagi selama tiga tahun terakhir.

\section{Disiplin Kerja}

Disiplin dapat didefinisikan sebagai atribut yang ditunjukkan oleh karyawan yang memungkinkan mereka untuk memenuhi atau melampaui harapan majikan mereka (Collins, 2018). Orang yang disiplin mampu mengendalikan perilaku, emosi, dan kondisi kesejahteraannya sendiri.

(Hasibuan, 2014) menyatakan bahwa disiplin kerja mempunyai indikator, sebagai berikut:

1) Tujuan Kemampuan

Tujuan yang ingin dicapai harus didefinisikan dengan jelas dan ideal dan cukup menantang untuk kemampuan karyawan. Dimensi tujuan kemampuan diukur dengan menggunakan dua indikator, yaitu:

a. Karyawan tiba ditempat kerja tepat waktu.

b. Intensitas kehadiran saat karyawan bekerja.

2) Tingkat Kewaspadaan Karyawan Karyawan yang selalu cermat dan akurat dalam bekerja sangat waspada terhadap diri sendiri dan pekerjaannya. Ada dua indikator untuk mengukur dimensi kewaspadaan, yaitu:

a. Kewaspadaan dan kehati-hatian dalam bekerja.

b. Merawat peralatan bekerja.

3) Mematuhi Standar Kerja

Karyawan harus mematuhi semua standar kerja yang ditetapkan sesuai dengan aturan dan pedoman kerja saat bekerja untuk menghindari kecelakaan atau menghindari kecelakaan. Ada tiga indikator untuk 
mengukur dimensi kepatuhan terhadap standar ketenagakerjaan, yaitu:

a. Rasa bertanggung jawab dalam bekerja.

b. Memahami fungsi dan tugasnya dalam bekerja

c. Bekerja sesuai jam kerja.

4) Mematuhi peraturan kerja.

Dirancang untuk kenyamanan dan kemudahan bekerja. Dimensi kepatuhan kerja dapat diukur dengan dua indikator, yaitu:

a. Pegawai memahami peraturan kerja.

b. Pekerjaan dapat diselesaikan sesuai dengan peraturan kerja.

5) Etika kerja

Setiap karyawan harus melakukan pekerjaannya dengan baik agar tercipta suasana yang harmonis dan saling menghormati antar rekan kerja. Ada satu indikator untuk mengukur dimensi etika kerja, yaitu:

a. bersikap dan berperilaku baik dalam bekerja.

\section{Kompetensi Karyawan}

Kompetensi adalah kebutuhan untuk merasa efektif dalam melakukan pekerjaan dan memperluas keterampilan (Fowler, 2014). Kompetensi merupakan sifat-sifat yang terkait dengan kemampuan dan efektivitas yang dirasakan, seperti pengetahuan, keterampilan, efisiensi, ketelitian dan kecerdasan (Cuddy, Fiske, \& Glick, 2008).

Kompetensi karyawan yang lebih besar mengarah untuk niat pelanggan yang lebih tinggi agar kembali dan merekomendasikan toko, dan itu akan meningkatkan penjualan, kepuasan, kualitas layanan, dan loyalitas (Brexendorf, Mühlmeier, Tomczak, \& Eisend, 2010; Wu, Tsai, Hsiung, \& Chen, 2015; Rod, Ashill, \& Gibbs, 2016). Pada sisi yang lain emosi positif, dan niat untuk merekomendasikan toko serta mengurangi perasaan negatif (Fernández-Sabiote \& Román, 2016; LuciaPalacios, Pérez-López, \& Polo-Redondo, 2018).

(Sutrisno, 2011) menyatakan indikator kompetensi karyawan sebagai berikut:

a) Pengetahuan

Kesadaran di bidang kognisi, karyawan harus bisa belajar dengan baik sesuai kebutuhan perusahaan.

b) Pemahaman
Karyawan memiliki kedalaman kognisi dan emosi, dapat belajar, dan memiliki pemahaman yang efektif dan efisien tentang karakteristik dan kondisi kerja.

c) Sikap Kerja

Perasaan atau sikap karyawan terhadap peristiwa atau masalah dari pekerjaan atau diluar pekerjaan.

d) Kemampuan

Kemampuan karyawan untuk melakukan tugas yang diberikan kepadanya oleh perusahaan.

e) Minat

Sifat seorang karyawan, di mana ada kecenderungan atau minat untuk terlibat dalam pekerjaan tertentu.

\section{Kompensasi}

Kompensasi karyawan merupakan bagian dari manajemen sumber daya manusia dan dianggap penting dalam fungsi organisasi (Gupta \& Shaw, 2014).

Karyawan bergantung pada kompensasi untuk menjaga stabilitas dalam hidup mereka, sementara majikan mengandalkan kemampuan dan kinerja karyawan untuk mempertahankan daya saing di pasar (Kim \& Jang, 2020).

Karyawan bekerja untuk mendapatkan penghargaan dengan menerima kompensasi sesuai dengan imbalan untuk layanan yang diberikan. Penghargaan dapat berupa kompensasi yang merupakan faktor penting yang menjadi perhatian setiap orang dalam perusahaan untuk memenuhi kepuasan dan untuk meningkatkan kinerja (Saban, Basalamah, Gani, \& Rahman, 2020).

Kompensasi adalah semua penghargaan yang diterima oleh karyawan sebagai imbalan atas kontribusi yang diberikan kepada perusahaan (Nguyen, Yandi, \& Mahaputra, 2020).

Konsep kompensasi yang diterapkan industri hotel mengacu pada pemahaman tentang klasifikasi kompensasi, di mana konsep kompensasi diketahui dalam dua bentuk umum yaitu kompensasi finansial dan kompensasi nonfinansial. Kompensasi finansial terdiri dari kompensasi langsung dan kompensasi tidak langsung, sedangkan bentuk kompensasi non-finansial berupa lingkungan dan fasilitas kerja yang tersedia (Stolovitch \& Keeps, 2007).

(Hasibuan, 2014) mengemukakan secara umum ada beberapa indikator kompensasi, yaitu: 
1) Kompensasi Langsung (Direct Compensation), seperti gaji, bonus dan insentif.

2) Kompensasi Tidak Langsung (Indirect Compensation), seperti: asuransi, Tunjangan Hari Raya (THR), tunjangan konsumsi dan fasilitas.

\section{Metode Penelitian}

Analisis data menggunakan deskriptif kuantitatif. Hasil penelitian dinarasikan dengan menggunakan rumus matematis dan statistik serta menghubungkannya dengan teori yang ada, kemudian akan ditarik sebuah kesimpulan dari permasalahan tersebut. Penelitian yang dilakukan saat ini menggunakan objek penelitian dari nilai seseorang, yaitu disiplin kerja, kompetensi dan kompensasi. Ketiga variabel tersebut merupakan objek penelitian, kemudian akan ditarik sebuah kesimpulan, apakah ketiga variabel tersebut saling berkaitan satu sama lain.

\section{Populasi dan Sampel}

(Arikunto, 2013) menyatakan populasi adalah subjek penelitian. Jika seseorang ingin memeriksa semua elemen yang ada di lapangan penelitian, maka penelitiannya adalah penelitian populasi. Selain populasi, dalam penelitian kuantitatif juga terdapat sampel. Sampel adalah sebagian atau wakil populasi yang diteliti. Populasi dalam penelitian ini merupakan seluruh karyawan yang bekerja di Hotel Selabintana yang berjumlah 137 orang karyawan. Sampel yang digunakan dalam penelitian ini sebanyak 102 orang karyawan Hotel Selabintana yang akan menjadi responden. Hal ini dilakukan untuk mempermudah penelitian dalam pengolahan data untuk pengujian yang lebih baik.

\section{Teknik Penentuan Ukuran Sampel}

Penentuan sampel menggunakan rumus Slovin sebagai berikut:

$$
\mathrm{n}=\frac{N}{1+N(e)^{2}}
$$

Keterangan :

$\begin{array}{ll}\mathrm{n} & : \text { Ukuran sampel atau jumlah } \\ \mathrm{N} & \text { : Ukuran populasi }\end{array}$

e

$$
\begin{aligned}
& \text { : Batas toleransi kesalahan, } \\
& \text { sebesar } 5 \%
\end{aligned}
$$

Berdasarkan rumus tersebut, maka jumlah sampel yang diambil dalam penelitian ini adalah sebagai berikut:

$$
\begin{aligned}
& \mathrm{n}=137 /\left(1+137(0,05)^{2}\right) \\
& \mathrm{n}=137 /(1+137(0,0025) \\
& \mathrm{n}=137 /(1+0,3425) \\
& \mathrm{n}=137 / 1,3425 \\
& \mathrm{n}=102,0484 \\
& \mathrm{n}=102 \text { responden }
\end{aligned}
$$

Dari hasil perhitungan di atas, maka sampel yang digunakan dalam penelitian ini sebanyak 102 orang karyawan Hotel Selabintana yang akan menjadi responden. Hal ini dilakukan untuk mempermudah penelitian dalam pengolahan data untuk pengujian yang lebih baik.

\section{Operasional Variabel}

(Sugiyono, 2017) menyatakan bahwa variabel penelitian adalah segala sesuatu dalam bentuk apapun yang ditentukan oleh seorang peneliti untuk memperoleh informasi dan kemudian menarik suatu kesimpulan. Pada penelitian ini yang menjadi variabel $\mathrm{X} 1$ yaitu Disiplin Kerja dan variabel $\mathrm{X} 2$ yaitu Kompetensi Karyawan. Sedangkan yang menjadi variabel $\mathrm{Y}$ adalah Kompensasi.

\section{Model Analisis} 2 berikut:

Model analisis terlihat pada gambar

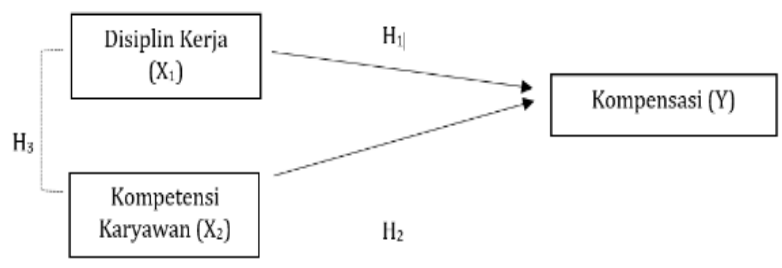

Gambar 2. Model Analisis Penelitian

\section{Hipotesis}

Tujuan penelitian untuk menguji seberapa berpengaruh antara variabel berikut ini, variabel disiplin kerja karyawan dengan kompensasi, variabel kompetensi karyawan dengan kompensasi. Dengan hipotesis sebagai berikut: 
$\mathrm{HO}_{1}$ : Disiplin kerja tidak berpengaruh positif terhadap kompensasi di Hotel Selabintana.

$\mathrm{Ha}_{1}$ : Disiplin kerja berpengaruh positif terhadap kompensasi di Hotel Selabintana.

$\mathbf{H O}_{2}$ : Kompetensi karyawan tidak berepengaruh postif terhadap kompensasi di Hotel Selabintana.

$\mathrm{Ha}_{2}$ : Kompetensi karyawan berpengaruh positif terhadap kompensasi di Hotel Selabintana.

$\mathrm{HO}_{3}$ : Disiplin kerja dan kompetensi karyawan tidak berpengaruh positif terhadap kompensasi di Hotel Selabintana.

$\mathrm{Ha}_{3} \quad$ : Disiplin kerja dan kompetensi karyawan berpengaruh positif terhadap kompensasi di Hotel Selabintana.

\section{Teknik Pengumpulan Data}

Teknik pengumpulan data yang di gunakan dalam penelitian disini meliputi :

a. Kuesioner

Penelitian ini menggunakan kuesioner berupa pertanyaan atau pernyataan tertulis yang diisi oleh para responden.

b. Analisis Dokumen

Analisis dokumen penelitian ini menggunakan dokumen absensi kehadiran karyawan dan jumlah karyawan yang bekerja di Hotel Selabintana.

\section{Pengujian Instrumen}

a. Uji Validitas

Uji validitas digunakan untuk mengukur sah atau tidak sahnya suatu kuesioner dengan mengkomparasikan nilai $r$ hitung dengan $r$ tabel. Jika $r$ hitung $>r$ tabel, maka item-item pertanyaan dinyatakan valid dan sebaliknya, jika $r$ hitung $<r$ tabel, maka item-item pertanyaan dinyatakan tidak valid.

\section{b. Uji Reliabilitas}

Selain uji validitas, dilakukan juga uji reliabilitas kepada keseluruhan sampel yang berjumlah 102 responden. Uji reliabilitas dilakukan pada butir-butir pernyataan yang telah valid. Teknik untuk menguji reliabilitas instrumen yaitu dengan menggunakan metode cronbach's alpha dimana variabel tersebut akan dinyatakan reliabel dengan ketentuan, jika nominal reliabilitas kurang dari 0,6 maka nilainya kurang baik. Artinya adalah bahwa alat ukur yang digunakan tidak reliabel.

\section{Uji Asumsi Klasik}

a. Uji Normalitas

Pada penelitian ini uji normalitas dilakukan bertujuan untuk mengetahui normal atau tidaknya suatu distribusi data. Pada uji normalitas ini, pengujian dilakukan pada variabel Disiplin Kerja (X1), Kompetensi Karyawan (X2), dan Kompensasi (Y). Penelitian ini menggunakan Kolmogrov Smirnov Goodness of Fit Test untuk melihat apakah data berdistribusi normal atau tidak. Selain itu, data ini juga dibandingkan dengan Normality Probability Plot.

Adapun kriteria dalam uji normalitas ini adalah :

1) Angka sig. Uji Kolmogrov - Smirnov > 0,05 maka berdistribusi normal.

2) Angka sig. Uji Kolmogrov - Smirnov < 0,05 maka berdistribusi tidak normal

b. Uji Multikolinieritas

Uji multikolinearitas dapat dideteksi dengan menilai koefisien ganda dan mengkomparasikan dengan koefisien korelasi antar variabel bebas. Uji multikolinearitas dapat dilakukan dengan menggunakan uji regresi, sebagai nilai standar VIF (Variance Inflation Factor) dan koefisien korelasi antara variabel bebas.

Kriteria yang digunakan adalah sebagai berikut:

a) Jika nilai VIF di sekitar angka 1 atau memiliki toleransi mendekati 1 , maka dikatakan tidak terdapat masalah multikolinearitas.

b) Jika koefisien antar variabel bebas kurang dari 0.5 , maka tidak terdapat masalah multikolinearitas.

c. Uji Heteroskedastisitas

Uji heteroskedastisitas digunakan untuk melihat apakah model regresi muncul ketidaksamaan variabel dari residual satu observasi ke observasi lainnya. Varian dari residual dari satu observasi ke observasi lainnya tetap, maka disebut homoskedastisitas, jika terjadi perbedaan disebut heteroskedastisitas. Model regresi yang baik tidak terjadi heteroskedastisitas (Mudawaroch \& Rinawidiastuti, 2020). Pada penelitian ini, uji heteroskedastisitas menggunakan uji scatter - plots.

Adapun kriteria dalam uji scatter - plots adalah :

1) Titik-titik pada scatter - plots menyebar secara random, dari bagian atas angka nol sampai di bagian bawah angka nol dari aksis vertikal atau aksis $\mathrm{Y}$, maka 
disimpulkan bahwa tidak terjadi heteroskedastisitas.

2) Titik - titik pada scatter - plots menyatu secara dinamis, baik di bagian atas angka nol ataupun di bagian bawah angka nol dari aksis vertikal atau aksis Y, maka disimpulkan bahwa terjadi heteroskedastisitas.

\section{Pengujian Hipotesis}

a. Analisis Regresi Linear Berganda

(Nazir, 2011) menyatakan bahwa analisis linear berganda digunakan oleh peneliti dimaksudkan untuk meramal bagaimana keadaan (naik turun) variabel dependen (kriterium), bila dua atau lebih variabel independen sebagai faktor prediktor dimanipulasi (dimodifikasi naik turun). Menurut (Sugiyono, 2014) rumus persamaan regresi berganda yang ditetapkan adalah:

$$
Y=\alpha+\beta_{1} x_{1}+\beta_{2} x_{2}
$$

Keterangan:

$$
\begin{array}{ll}
\mathrm{Y} & : \text { Variabel dependen } \\
\underline{\alpha} & : \text { Koefisien konstanta } \\
\mathrm{B}_{1}, \beta_{2} & : \text { Koefisien regresi } \\
\mathrm{X}_{1} & : \text { Variabel terikat 1 } \\
\mathrm{X}_{2} & : \text { Variabel terikat } 2
\end{array}
$$

Untuk melihat besarnya persentase sumbangan variabel pengaruh terhadap variabel terpengaruh secara keseluruhan digunakan rumus koefisien determinasi sebagai berikut :

$$
R_{2}=\frac{b_{1} \sum X_{1} Y_{1}+b_{2} \sum X_{2} Y_{2}}{\sum Y_{1}^{2}}
$$

\section{b. Uji t (Signifikan Parsial)}

Uji statistik t disebut juga sebagai uji signifikan individual yaitu menunjukkan sampai sejauh mana pengaruh variabel bebas terhadap variabel terikat secara parsial. Dasar pengambilan keputusan pengujian menggunakan uji $t$ yaitu dengan membandingkan thitung dengan tabel dengan ketentuan sebagai berikut:

$\mathrm{H} 0: \beta=0$ variabel bebas (independent) tidak ada pengaruh secara parsial atau individual terhadap variabel tidak bebas (dependent).

$\mathrm{Ha}: \beta \neq 0$ variabel bebas (independent) berpengaruh secara parsial atau individu terhadap variabel tidak bebas (dependent).
Hasil hipotesis thitung dibandingkan dengan tabel dengan kriteria uji sebagai berikut:

1) Jika thitung $>$ tabel pada $\underline{\alpha}=5 \%$ maka $\mathrm{Ha}$ diterima dan Ho ditolak, berarti ada pengaruh antara masing-masing variabel bebas (independent) dan variabel tidak bebas (dependent).

2) Jika thitung $<$ tabel pada $\underline{\alpha}=5 \%$ maka Ho diterima dan $\mathrm{Ha}$ ditolak, berarti tidak ada pengaruh antar masing-masing variabel bebas (dependent) dan varaibel tidak bebas (independet).

\section{c. Uji F (Uji Simultan)}

Uji $\mathrm{F}$ digunakan untuk melihat apakah variabel bebas secara simultan (serentak) mempunyai pengaruh terhadap variabel terikat, bentuk pengujiannya sebagai berikut:

Ho : $\beta=0$, artinya tidak terdapat pengaruh disiplin kerja dan kompetensi karyawan terhadap kompensasi.

$\mathrm{Ha}: \beta \neq 0$, artinya terdapat pengaruh disiplin kerja dan kompetensi karyawan terhadap kompensasi.

(Sugiyono, 2017) mengemukakan bahwa pengujian hipotesis dapat menggunakan rumus signifikan korelasi ganda, sebagai berikut:

$$
\mathrm{F}=\frac{\mathrm{R}^{2} / \mathrm{k}}{\left(1-\mathrm{R}^{2}\right) /(\mathrm{n}-\mathrm{k}-1)}
$$

Keterangan :

$$
\begin{array}{ll}
\mathrm{R} & : \text { Koefisien korelasi ganda } \\
\mathrm{K} & : \text { Jumlah variabel independen } \\
\mathrm{n} & : \text { Jumlah anggota sampel } \\
\mathrm{dk} & :(\mathrm{n}-\mathrm{k}-1) \text { derajat kebebasan }
\end{array}
$$

Pengujian dengan membandingkan $F_{\text {hitung }}$ dengan $F_{\text {tabel }}$ dengan ketentuan sebagai berikut:

1) Jika Fhitung $>F_{\text {tabel }}$ pada $\underline{\alpha}=5 \%$ maka $\mathrm{Ha}$ diterima dan Ho ditolak (berpengaruh).

2) Jika F hitung $<F_{\text {tabel }}$ pada $\underline{\alpha}=5 \%$ maka Ho diterima dan $\mathrm{Ha}$ ditolak (tidak berpengaruh).

\section{Hasil dan Pembahasan Uji Validitas}

Hasil dari uji Validitas dengan jumlah 30 responden dan tingkat signifikan $5 \%$, maka $r$ tabel dalam penelitian ini adalah 0,361 dan $r$ hitung memiliki nilai 
yang lebih besar sehingga seluruh item pernyataan dinyatakan valid.

\section{Uji Reliabilitas}

Hasil olah data dari uji reliabilitas diperoleh hasil seluruh butir (item) pernyataan yang digunakan adalah reliabel karena nilai Cronbach's Alpha > 0,60, sehingga kusioner yang digunakan dapat dikatakan layak dan dipercaya sebagai instrumen untuk melakukan pengukuran setiap indikator variabel dan analisis data selanjutnya.

\section{Uji Normalitas}

Berdasarkan hasil uji normalitas menunjukkan bahwa kolmogorov-smirnov memiliki nilai Asymp. Sig. (2-tailed) adalah 0,351 , artinya nilai signifikasi tersebut lebih besar daripada 0,05 , yaitu $(0,351>0,05)$ sehingga dapat disimpulkan bawa data dalam penelitian ini berdistribusi normal.

\section{Uji Multikolonieritas}

Berdasarkan hasil uji multikolonieritas menunjukkan bahwa variabel Disiplin Kerja dan Kompetensi Karyawan memiliki nilai tolerence 0,197 dan nilai VIF sebesar 5.085. Karena nilai tolerence $(0,197>0.10)$ dan nilai VIF $(5.085<$ 10), sehingga dapat disimpulkan bahwa variabel $\mathrm{X}_{1}$ dan $\mathrm{X}_{2}$ dinyatakan tidak terjadi multikolinieritas, sehingga hasil pengujian dikatakan reliabel dan terpercaya.

\section{Uji Heteroskedastisitas}

Berdasarkan hasil uji

heterokedastisitas menunjukkan bahwa sebaran data menyebar di bawah dan di atas titik nol, sehingga dapat disimpulkan bahwa pengaruh variabel $X_{1}$ dan $X_{2}$ terhadap variabel $Y$ tidak terjadi masalah heteroskedastisitas pada model regresi, artinya tidak adanya penyimpangan dari asumsi klasik pada data yang dilakukan dalam pengujian ini.

\section{Analisis Regresi Linear Berganda}

Analisis regresi ini digunakan untuk menghitung besarnya pengaruh antara variabel bebas, yaitu Disiplin Kerja $\left(\mathrm{X}_{1}\right)$ dan Kompetensi Karyawan $\left(\mathrm{X}_{2}\right)$ terhadap variabel terkait yaitu Kompensasi (Y). Berdasarkan pengolahan data dapat dilihat hasil analisis regresi linear berganda, memperoleh model regresi sebagai berikut: $Y=4,899+0,260 * X_{1}+0,636 * X_{2}$

Dari model regresi tersebut dapat diinterpretasikan sebagai berikut: $a=4,899$, hasil ini menunjukkan bahwa tanpa adanya pengaruh dari variabel bebas terhadpa variabel $Y$ (Kompensasi), maka total skor variabel $Y$ adalah sebesar 4,899 .

$b_{1}=0,260$, hasil ini menunjukkan bahwa apabila terdapat kenaikan satu skala tanggapan terhadap variabel $\mathrm{X}_{1}$, maka akan terjadi peningkatan pada total skor variabel $Y$ sebesar 0,260. Jadi, apabila terjadi peningkatan pada variabel $X_{1}$ maka variabel $Y$ pun akan meningkat.

$b_{2}=0,636$, hasil ini menunjukkan bahwa apabila terdapat kenaikan satu skala tanggapan terhadap variabel $\mathrm{X}_{2}$, maka akan terjadi peningkatan pada total skor variabel $Y$ sebesar 0,636. Jadi apabila terjadi peningkatan pada variabel $\mathrm{X}_{2}$ maka variabel $Y$ pun akan meningkat.

\section{Uji t (Signifikan Parsial)}

Hasil olah data dari uji $t$ menunjukkan bahwa variabel disiplin kerja dalam thitung sebesar 4,265 dengan nilai signifikan 0,000 . Untuk mengetahui nilai ttabel, distribusi t dicari pada nominal $a=5 \%$ : $2=2,5 \%$ (Uji 2 sisi) dengan derajat kebebasan (df) $n-k$ atau $102-3=99$ ( adalah jumlah responden dan $\mathrm{k}$ adalah jumlah variabel), dengan pengujian 2 sisi (signifikan $=0,025$ ) maka diperoleh hasil tabel yaitu sebesar 1,985. Karena nilai thitung lebih besar dari tabel $(4,265>1,985)$ dan nilai signifikan lebih kecil dari 0,05 $(0,000<0,05)$, maka $\mathrm{HO}_{1}$ ditolak dan $\mathrm{Ha}_{1}$ diterima. Pengujian ini menunjukkan bahwa variabel Disiplin Kerja $\left(X_{1}\right)$ berpengaruh secara signifikan tehadap variabel Kompensasi (Y).

Hasil uji $\mathrm{t}$ variabel Kompetensi Karyawan memperoleh nilai thitung sebesar 6,529 dengan nilai signifikan 0,000. Karena nilai thitung lebih besar dari nilai tabel $(6,529>1,985)$ dan nilai signifikan lebih kecil dari $0,05(0,000<0,05)$ maka $\mathrm{HO}_{2}$ ditolak dan $\mathrm{Ha}_{2}$ diterima. Pengujian ini menunjukkan bahwa variabel Kompetensi Karyawan $\left(\mathrm{X}_{2}\right)$ berpengaruh secara signifikan terhadap variabel Kompensasi (Y).

\section{Uji F (Uji Simultan)}

Berdasarkan hasil uji $f$ menunjukkan bahwa nilai $F_{\text {hitung }}$ sebesar 281,549 dengan nilai signifikan 0,000 . Nilai $F_{\text {tabel dapat ditentukan dengan }}$ menggunakan tingkat kepercayaan 0,05 atau $5 \%$ dengan rumus $d f 1=k-1$ yaitu 
df $1=3-1=2$ dan df2 $=n-k$ yaitu $102-3=$ 99. Maka dapat diperoleh nilai $F_{\text {tabel }}$ sebesar 3,09 . Karena $F_{\text {hitung }}$ lebih besar dari $F_{\text {tabel }}$ $(281,549>3,09)$ dan nilai signifikan lebih kecil dari $0,05 \quad(0,000<0,05)$ maka $\mathrm{HO}_{3}$ ditolak dan $\mathrm{Ha}_{3}$ diterima. Hasil pengujian ini dapat disimpulkan bahwa secara simultan atau serentak variabel Disiplin Kerja $\left(X_{1}\right)$ dan Kompetensi Karyawan $\left(X_{2}\right)$ berpengaruh secara signifikan terhadap variabel Kompensasi $(\mathrm{Y})$.

\section{Koefisien Determinasi (R2)}

Hasil uji koefisien determinasi menunjukkan bahwa nilai koefisien determinasi (Adjusted $R$ Square) sebesar 0,847. Hal ini menjelaskan bahwa sumbangan atau kontribusi dari variabel bebas atau independen Disiplin Kerja (X1) dan Kompetensi Karyawan (X2) terhadap variabel terikat atau dependen Kompensasi (Y) adalah sebesar $84,7 \%$. Sedangkan sisanya $(100 \%-84,7 \%=15,3 \%)$ dipengaruhi oleh variabel-variabel lain yang tidak diteliti dalam penelitian ini.

\section{Kesimpulan}

Berdasarkan hasil dan pembahasan dapat disimpulkan bahwa disiplin kerja berpengaruh terhadap kompensasi yang diterima oleh karyawan. Artinya secara signifikan disiplin kerja mampu memberikan dampak bagi kompensasi agar karyawan bekerja sesuai dengan kebijakan yang diterapkan dan sesuai dengan visi dan misi perusahaan. Kemudian untuk kompetensi berpengaruh signifikan terhadap kompensasi yang diterima karyawan. Artinya kompetensi yang dimiliki oleh karyawan mampu dimanfaatkan secara maksimal untuk meningkatkan kompensasi yang nantinya akan diterima. Selanjutnya disiplin kerja dan kompetensi secara bersama-sama berpengaruh terhadap kompensasi yang diterima karyawan. Artinya kedua variabel bebas tersebut mampu memberikan stimulan bagi karyawan dalam meningkatkan kinerjanya yang akan memberikan dampak pada kompensasi yang akan diterima.

Secara teoritis hasil penelitian ini dapat dijadikan rekomendasi atau dapat dikembangkan lebih lanjut bagi penelitian selanjutnya dengan obyek dan variabel penelitian yang berbeda sehingga dapat ditemukan faktor-faktor lainnya yang mempengaruhi pemberian kompensasi.
Selain itu, dengan adanya hasil penelitian ini dapat dijadikan bahan kajian, evaluasi dan diskusi di suatu perusahaan yang sedang mengalami masalah yang sama, yaitu mengenai pengaruh disiplin kerja dan kompetensi karyawan terhadap kompensasi.

\section{Referensi}

Ariani, H. P., \& Widodo, S. (2020). Pengaruh Disiplin Kerja Dan Kompensasi Terhadap Kinerja Karyawan Pt. Yamaha Music Indonesia, Jakarta. Jurnal IImiah Mahasiswa Manajemen Unsurya, 1(1), 31-41.

Arikunto, S. (2013). Prosedur penelitian suatu pendekatan praktik. Jakarta: Rineka Cipta.

Brexendorf, T. O., Mühlmeier, S., Tomczak, T., \& Eisend, M. (2010). The impact of sales encounters on brand loyalty. Journal of Business Research, 63(11), 1148-1155.

https://doi.org/10.1016/j.jbusres.2009. 10.011

Collins, J. (2018). Progressive Discipline. HR Management in the Forensic Science Laboratory, 383-404. https://doi.org/10.1016/b978-0-12801237-6.00022-1

Cuddy, A. J. C., Fiske, S. T., \& Glick, P. (2008). Warmth and Competence as Universal Dimensions of Social Perception: The Stereotype Content Model and the BIAS Map. Advances in Experimental Social Psychology, 40(07), 61-149. https://doi.org/10.1016/S00652601(07)00002-0

Fernández-Sabiote, E., \& Román, S. (2016). The multichannel customer's service experience: building satisfaction and trust. Service Business, 10(2), 423-445. https://doi.org/10.1007/s11628-0150276-z

Fowler, S. (2014). Why motivating people doesn't work... and what does: the new science of leading, energizing, and engaging. Berrett-Koehler Publishers.

Gupta, N., \& Shaw, J. D. (2014). Employee compensation: The neglected area of HRM research. Human Resource Management Review, 24(1), 1-4. https://doi.org/10.1016/j.hrmr.2013.08. 007 
Hasibuan, M. S. (2014). Manajemen Sumber Daya Manusia (14th ed.). Jakarta: Bumi Aksara.

Kim, H. S., \& Jang, S. C. (Shawn). (2020). The effect of increasing employee compensation on firm performance: Evidence from the restaurant industry. International Journal of Hospitality Management, 88(August 2019), 102513.

https://doi.org/10.1016/j.jhm.2020.102 513

Lina, R. (2020). Pengaruh Rekrutmen Terhadap Kinerja Karyawan. Scientific Journal of Reflection: Economic, Accounting, Management and Business, 3(3), 281-290. https://doi.org/10.5281/zenodo.39306 94

Lucia-Palacios, L., Pérez-López, R., \& Polo-Redondo, Y. (2018). Can social support alleviate stress while shopping in crowded retail environments? Journal of Business Research, 90(February 2017), 141150.

https://doi.org/10.1016/j.jbusres.2018. 05.018

Mudawaroch, R. E., \& Rinawidiastuti. (2020). Faktor-Faktor Yang Mempengaruhi Keputusan Mahasiswa Membeli Makanan Bergizi. In Seminar Teknologi Agribisnis Peternakan (STAP) Fakultas Peternakan Universitas Jenderal Soedirman (pp. 138-145).

Mulyapradana, A., Rosewati, T., \& Muafiq, F. (2020). Pengaruh Pemberian Kompensasi terhadap Kinerja Karyawan Hotel Dafam Kota Pekalongan. Widya Cipta: Jurnal Sekretari Dan Manajemen, 4(1), 2733.

https://doi.org/10.31294/widyacipta.v4i 1.6585

Nazir, M. (2011). Metode Penelitian. Bogor: Ghalia Indonesia.

Nguyen, P. T., Yandi, A., \& Mahaputra, M. R. (2020). Factors that influence employee performance: motivation, leadership, environment, culture organization, work achievement, competence and compensation (A study of human resource management literature studies). Dinasti International Journal of Digital Business Management, 1(4), 645662. https://doi.org/10.31933/DIJDBM

Pratama, A. (2020). Pengaruh Kompensasi Dan Disiplin Kerja Terhadap Kinerja Karyawan Pada PT Pos Indonesia DC Ciputat. Jurnal Disrupsi Bisnis : Jurnal Ilmiah Prodi Manajemen, Fakultas Ekonomi, Universitas Pamulang, 3(2), 12.

https://doi.org/10.32493/drb.v3i2.6293

Rod, M., Ashill, N. J., \& Gibbs, T. (2016). Customer perceptions of frontline employee service delivery: A study of Russian bank customer satisfaction and behavioural intentions. Journal of Retailing and Consumer Services, 30, 212-221.

https://doi.org/10.1016/j.jretconser.201 6.02 .005

Saban, D., Basalamah, S., Gani, A., \& Rahman, Z. (2020). Impact Of Islamic Work Ethics, Competencies, Compensation, Work Culture On Job Satisfaction And Employee Performance: The Case Of Four Star Hotels. European Journal of Business and Management Research, 5(1), 18.

https://doi.org/10.24018/ejbmr.2020.5. 1.181

Stolovitch, S., \& Keeps, S. (2007). Managing Resource and Performance. Buckingham: Open University $\mathrm{Pr}$.

Sugiyono. (2014). Metode Penelitian Kuantitatif Kualitatif dan $R \& D$. Bandung: CV. Alfabeta.

Sugiyono. (2017). Metode Penelitian Kuantitatif Kualitatif dan $R \& D$. Bandung: Alfabeta.

Sutrisno, E. (2011). Manajemen Sumber Daya Manusia. Jakarta: Kencana.

Wu, Y.-C., Tsai, C.-S., Hsiung, H.-W., \& Chen, K.-Y. (2015). Linkage between frontline employee service competence scale and customer perceptions of service quality. Journal of Services Marketing, 29(3). https://doi.org/http://dx.doi.org/10.110 8/JSM-02-2014-0058 